possibilities (and so many fireworks) that it stands a fair chance of combating any end-of-semester depression that may infiltrate our closing discussion of piety and death.

\section{Philosophy/Political Science 306 Origins of Philosophy: China and Greece}

A consideration of the period between the 6th and the 3rd centuries B.C., when certain individuals in both China and Greece began to regard critically and self-consciously the cultures in which they lived.

Requirements: Students are expected to do the assigned readings before coming to class; informed participation in class discussion will be an element of the final grade. There will be four short papers (total length: $20-25$ pages) as indicated below. These will be interpretive essays on the texts we consider in class. There will be a self-scheduled final examination.

Schedule of Readings and Papers

January 19: Introduction

January 21: Benjamin Schwartz, Introduction and Chapter 1 from The World of Thought in Ancient China (xeroxed handout)
January 26 and 28: Cho-yun Hsu, Ancient China in Transition Frank J. Frost, Greek Society, chs. 1-5

February 2 and 4: Confucius (551-479): Anlects, esp. Chs. 1-9, 12, 13 Thucydides (about 460-400): The Peloponnesian War (pp. 35-49, 72-87, 143-164, 212-245, 400-437, 455-470, 516-537)

February 9 and 11: Confucius and Thucydides

February 16: Confucius and Thucydides

February 17: First Paper Due, 5 P.M.

February 18: Chuang Tzu (between 339 and 295) Heraclitus (fl. 500) and Parmenides (fl. 475), Fragments (xeroxed handout)

February 23 and 25: Chuang Tzu and Pre-Socratics

March 1 and 3: Chuang Tzu and PreSocratics

March 4: Second Paper Due, 5 P.M.

Spring Break

March 15 and 17: Mencius (371-289?) Plato (429-347): Phaedrus

March 22 and 24: Mencius and Phaedrus

March 29 and 31: Mencius and Phaedrus
April 4: Third Paper Due, 5 P.M.

April 5 and 7:Hsün Tzu (fl. 298-238) Aristotle (384-322): Nicomachean Ethics

April 12 and 14: Hsün Tzu and Aristotle, Parts of Animals, Book 1 (xeroxed handout)

April 19 and 21: Hsün Tzu and Aristotle April 26 and 28: Hsün Tzu and Aristotle Final Paper Due-Last Day for Written Work

\begin{abstract}
About the Authors
Stephen G. Salkever is Mary Katherine Woodworth Professor of Political Science at Bryn Mawr College. He is the author of Finding the Mean: Theory and Practice in Aristotelian Political Philosophy (paperback re-issue, 1994).

Michael Nylan is associate professor of East Asian Studies at Bryn Mawr College. She has written two books on early Chinese political philosophy: The Shifting Center: The Original "Great Plan" and Later Readings (1992) and The Canon of Supreme Mystery by Yang Hsiung (1993).
\end{abstract}

\title{
Space Bridges: The U.S.-Soviet Space Bridge Resource Center
}

\author{
Helene Keyssar, University of California, San Diego
}

The airing in the Soviet Union of the Donahue space bridges transformed the Soviet public's image of itself." Interview with Vladimir Pozner, Moscow, 1989

After Remembering War, when I toured the Soviet Union as a musician, even in the remotest village, people came up and hailed me as a hero.

S. Frederick Starr, President, Oberlin College, jazz clarinetist, Sovietologist and U.S. moderator for Remembering War

\section{The Growth of a Medium}

During the decade 1982-92, groups in the United States joined with various Soviet institutions to develop new forms of communication between citizens of the United States and the former Soviet Union. They did so in an era that began with deep mutual mistrust and ended in bewilderment, an era that began with the president of the United States referring to the Soviet Union as the "evil empire," and ended with the dissolution of the Soviet Union itself.

One result of efforts to exploit and effect changing climates of opinion in both the United States and the Soviet Union has been the emergence of a new cultural form called the "space bridge." Translated from the Russian word, telemost, a space bridge is an inter- active television link between at least two geographically separate and culturally distinct locations.

In contrast to teleconferences, space bridges are public events. Whereas teleconferencing brings together small groups for specialized discussions or lectures on interactive television, space bridges are more like interactive theater, in which the dialogue occurs between sites as well as between key participants, moderators, and unnamed audience members. Space bridges provide a space in which ordinary citizens can appear in public as a public.

I first became interested in space bridges in the summer of 1983 . 
Michael Cole, a cross-cultural cognitive psychologist and my colleague in the Department of Communication at the University of California, San Diego, had been at meetings in Moscow with Soviet psychologists. Late one evening, as Cole and his wife Sheila, a writer, were chatting with their old friend, Vladimir Pozner, a visitor burst into Pozner's apartment. The man, Joseph Goldin, had for many years been on the margins of Soviet life. He was a visionary, a dissident, and an entrepreneur, tolerated but often in trouble.

For some time Goldin had been thinking about using new communications technologies, especially satellites and large video screens, to link peoples around the world. In September of 1982 and, more successfully in May 1983, Goldin joined with Jim Hickman, then head of the Esalen Institute's Soviet-American Exchange Program, to produce video links with music groups and political and cultural figures in both countries. ${ }^{1}$

At Pozner's apartment, Goldin announced that Soviet television was going to air a segment of the May telecast, none of which had been previously broadcast. Goldin interpreted this as a clear gesture of support from the Soviet government and proposed that Michael and Sheila Cole initiate the next space bridge. Goldin assured the Coles that several American groups ranging from Esalen and Apple Computer to the Children's Television Workshop (producer of Sesame Street) would be helpful. Upon arrival in New York, the Coles determined that most of Goldin's "supporters" were unable or unwilling to help. They then called me. As the chair of UCSD's Department of Communication, I was in somewhat of a position to take on-or reject-such a project. I have some knowledge of the USSR, but more importantly, I am a theater director by training. With only a vague sense of what to do, I said I would investigate possibilities.

Despite the absence of concrete knowledge about the program, participants, or funding, on June 30 Cole and I sent a telegram to the
Soviets. It read, "We would like to invite you to participate with us in the production of a TV simulcast focused on children and film to be held during the Moscow Film Festival." Though the project was conceived by people in Moscow, our "invitation" was a recognition that they would not be able to realize its completion. Furthermore, if the event were approved and something went wrong-politically, aesthetically, fiscally-responsibility would lie on the U.S. side, where consequences were less serious.

What we came to call a "space bridge" was a deliberate experiment in communication based on the hypothesis that new understandings best emerge when communication is a mediated activity. In order for a fruitful exchange to

\section{Translated from the Russian word, telemost, a space bridge is an interactive television link between at least two geographically separate and culturally distinct locations.}

occur, both sides must agree beforehand on something to talk about. From the start, it was understood that while each side would be responsible for its own production costs and one-way satellite arrangements, we would collaborate on a script outline. It would be unproductive to simply put Soviets and Americans head-tohead and let them try to talk. By telephone, we in San Diego and our Soviet counterparts decided that short clips of parallel types of Soviet and American films and the presence of producers/directors would help direct the conversation between the Soviet and American audiences, of which most would be children.

Now including Sherman George, Director of Media at UCSD, and
Shanta Herzog, a children's film advocate, the U.S. group started operations. Every day at 8 a.m., Joseph Goldin called, often for an hour or more. At first, most of the suggestions for content and format came from the U.S. group. We pushed for some ideas from the Soviet side and were told that a "detailed script" and formal confirmation were on their way by telegram and telex.

For days, nothing arrived. Goldin's calls continued, however, and on that basis, we invited Robert Radnitz, a well-known Hollywood producer, the actress Shelly Duval and John Matthews, a director and producer of cartoons, to join the project. Our conversations with Goldin continued but as American commitments of time, money, and equipment were made, we began to get increasingly anxious for written confirmation. ${ }^{2}$ Then, one morning, Goldin did not call. Instead, we received a telegram, signed by a representative of GOSKINO, the Soviet Film Committee, which said that the Soviets were sorry but there was not enough time to produce the space bridge.

With no phone number for Goldin, no knowledge of the telegram's signer except that he was connected with GOSKINO and no luck reaching Vladimir Pozner, all we could do was wait. The next morning, Goldin's call came at 8:00. "Don't worry," he assured us, "It is all a mistake. There was confusion about the dates but if you will agree to postpone by a few days, everything will be fine." Delighted to have a few extra days, we sent another telegram naming a new date and requesting a time so we could reserve the satellite. We proceeded to make the appropriate changes until the next telegram came from Moscow almost a week later. The tone was less casual. "As we have said," it began, "there is insufficient time to do the space bridge that you propose." Perhaps in the indefinite future, but not now. Twenty hours later, Goldin again called and reassured us that the new telegram was also not to be taken seriously. Everything was going ahead in Moscow.

After a third negative telegram 
from Moscow arrived, we began to accept the improbability of mounting the event. Then, three days before the space bridge was to occur, we heard, from the first time in weeks, from Vladimir Pozner. He had not been arrested for unauthorized communications with Americans but had simply broken his wrist. He believed we could and should go ahead with the space bridge. There had, he hinted, been difficulties of a political nature. There was a turf war going on between GOSKINO and Gostelradio, the television and radio committee, sparked by Goldin's public declaration that television was only an instrument to be used by "creative" people, namely himself and his space bridge partners.

To continue our work on such a precarious basis meant risking not only face but money. Once we were within 24 hours of the event, we would lose thousands of dollars prepaid for the satellite feed. To make matters worse, the feed would now cost an extra $\$ 5,000$ because we had not made full payment on time. One of our funders agreed to pay the late fee if the event actually happened; if it did not, it would be up to UCSD to pay the bill.

To understand why we went ahead at that point requires recollection of the strain of the cold war and the growing fear of nuclear war in the early 1980 s. As our nuclear arsenals grew and as the voices of the leaders of both superpowers became increasingly shrill, ordinary citizens became frightened and frustrated. In the face of mutual distrust, pinning hopes for a less dangerous future on politicians seemed irresponsible. We were looking for an alternative way of making contact with "the other side." This is what space bridges offered.

On the day of the event, we had still not received any official written confirmation from Moscow that they were going to participate. A crucial phone call, scheduled for an hour before the event, never got through. From a room filled with children and film personalities, we sent our feed by microlink up to a satellite. We suddenly heard
Pozner: "Moscow calling San Diego. Moscow calling San Diego?"' "Yes, we can hear you," Mike Cole responded to a blank screen and, at the same time, Pozner announced, "We can see you. Can you see us?" Finally, Cole responded, "Yes, yes, we see you."

For many in both the Soviet and U.S. audiences, this was the first tine they had seen the "other." It was something of a victory when American television spectators noted that, from the visuals alone, they could not tell which children were Russian and which were American.

Like space bridges before and after, Moscow Calling San Diego: Children and Film was replete with mistakes and accidents. We learned, however, that unpredictable events revealed properties of each culture that are submerged when television is running smoothly.

An example of the power of imperfection occurred in Remembering War (May 1985), a UCSD/ Roosevelt Center for American Policy Studies space bridge that focused on the similarities and differences of World War II in the historical memories of Soviet and American citizens. Charlie Miller, a member of the American audience rose to speak about his experience as a POW. Miller spoke of being captured six times and escaping five times from German prison camps: "You must think me pretty dumb to keep being recaptured." The audience laughed empathetically; then Miller became more serious. He recalled how generous Soviet POWs had been to American prisoners and how cruelly Soviet prisoners were treated by the Germans. Almost too choked up to speak, Miller asserted, "No one had suffered as much as those Russians." He then turned awkwardly back and forth, uncertain of whom or what to address and, as he spoke, began to weep. After a long pause, he concluded, "I'm not going to apologize for my tears. Maybe if there were more of them like we see here today, maybe we wouldn't need all these summits and so on. ...."3

It was in the spirit of learning from previously silent sources that the UCSD group entered, as university researchers, into a longterm project that included both production of space bridges and research and data collection. ${ }^{4} \mathrm{We}$ had set out to demonstrate that a communication medium could compel people to reflect on their prior conceptions of how the world works. It was our intention to analyze what we had done away from the lunacy of production. This was not to be.

Within minutes of the finale of Children and Film, a Japanese producer called San Diego to say that they had pulled down part of the bridge and broadcast it in Japan; were we interested in including them in future bridges? Three days later, Tancred Golenpolsky, a wellknown Soviet writer called urging us to do another space bridge that September during the Moscow Book Fair. We resisted on the grounds that we had not assimilated what we had just done and had neither the money nor the energy to mount another event so quickly. The Soviets on the phone-a different group than previously-would hear none of it. When Gerald Peale of Scientific American magazine offered to pay all American costs, thus freeing our group in San Diego to focus on content and strategy, we acquiesced. By the beginning of August 1983, a much enlarged production committee at UCSD was back in space bridge production, this time putting together an event to be called The Earth in Word and Image..$^{5}$

However, as the use of communication satellites became commonplace, the novelty of the medium was no longer a sufficient attraction for money or interest. Voices on both sides called for "star" moderators and "hot" discussion topics. Gostelradio moved to establish a permanent space bridge subcommittee with its own funding. Everyone on both sides agreed that space bridges should be produced as a series of programs rather than individual events in order that producers could learn from their experiences and apply new knowledge to subsequent programs. 
With visions of significant increases in U.S. distribution and of more politically volatile program topics, the second stage of space bridge production began. Between 1985 and 1988, four American groups initiated a distinct series of space bridges. The first of these was a joint endeavor of the Roosevelt Center, the Department of Communication at UCSD, and Gostelradio. That series began with Remembering War (1985). More than 150 million Soviet citizens watched that prime-time broadcast; we estimate the U.S. audience for the PBS airings to have been about 20 million. Determined to increase the size of the U.S. audience, the Roosevelt Center-UCSD group initiated production of Glory Days, a bridge focused on the lives and values of young Soviets and Americans. It was put on hold, however, when WTTW, the Chicago PBS station that had agreed to be the U.S. host for the program, withdrew its support because of a public climate they judged to be hostile to space bridges. A year later, the Roosevelt Center itself closed its major offices, and the series ended prematurely.

A second space bridge series, initiated by the Documentary Guild and moderated by Phil Donahue in the U.S. and Vladimir Pozner in the USSR, began in December 1985. This series included Citizens Summit I (December 29, 1985), Citizens Summit II: Women to Women (May 20, 1986), and a link between Soviet and American journalists aired in the regular Donahue slot on February 10, 1987. Sometimes compared to New England town meetings, these television "summits" were open-ended discussions, with no central topics or limits. Donahue's domination of these space bridges and his aggressive, often hostile behavior towards members of the Soviet audience prompted mixed responses among American spectators and critics. Admittedly wary of being labeled a "Commie dupe" by the Western press, Donahue insistently used pejorative comments that embarrassed many American viewers.

Ironically, Donahue's technique combined with the reticence of most of the Soviet on-air audience, had a powerful effect on the Soviet television viewers. Soviet moderator Vladimir Pozner and Gostelradio received thousands of letters from Soviets who praised the candor of the American participants and criticized Soviet participants for their insincerity. Many viewers had never seen anything like this on television and were shocked that the government had allowed the programs to be broadcast. Soviets were ashamed of their self-presentation; they did not like seeing themselves as dishonest, uncritical, or ignorant as several of them appeared to be on camera. ${ }^{6}$ Seeing itself was as important to each group as seeing the other.

In 1987, the Capital to Capital space bridge series, moderated by ABC's Peter Jennings and Leonid Zolotarevsky, head of the International Department of Gostelradio, aired the first of at least five simulcasts linking key figures from the Soviet government with comparable figures from the U.S. government. Initially called "Congressbridges," these bridges focused on distinctly "hard news" topics such as mutual security and human rights. In the beginning, Jennings appeared to forget that there was a Soviet moderator as well as preprogram agreements about topics to be discussed. Jennings notes in "Telesummitry" that, after seeing the first two programs, President Mikhail Gorbachev called the Soviet producers before the Central Committee to tell them to be more vigorous. ${ }^{7}$ By the third bridge in this series, Jennings had mellowed, and Zolotarevsky had become more commanding. However, the success of bringing high-profile people into the space bridge arena also contributed to the subsequent disappointment many spectators expressed in the absence of dialogue and the posturing of public figures.

Finally, the most recent series to emerge, the Global Classroom bridges between Tufts University and Moscow University, have aired seven dialogues focused on U.S.Soviet relations and on the future of U.S.-Russian relations. The $\mathrm{Cu}$ ban Missile Crisis, the environment, and nuclear disarmament were among topics discussed in these bridges. Experts on a topic join university students from both cultures to conduct sophisticated conversations. This series sees itself as ongoing, preferably in association with other universities.

These four series dominated the space bridge medium during the mid- and late-80s. In addition, at least half a dozen other space bridges have been produced from as many locales in the United States, with considerable efforts to diversify broadcast sites in Russia and other former Soviet republics.

\section{Summary of Research Findings}

Soviet-American citizen perceptions of each other were transformed almost beyond recognition in the mid- to late-1980s. My research-which includes interviews, surveys, letters, textual and linguistic analyses, and reports of focus groups-suggests that space bridges contributed to these changes in perception but did more in the former Soviet Union than in the United States. The following are tentative conclusions.

First, and most generally, space bridges made a difference in SovietAmerican perceptions of each other, but the nature of that difference is other than what was imagined or intended by those who worked on them. A common expectation among sponsoring groups, producers, moderators, and participants was that through these programs, Americans and Soviets would "really get to understand each other better" and that this would lessen our fear of each other. The imprecision of media effects research makes it impossible to assert with certainty the degree to which this occurred, and my own attempts to make such distinctions from my data only confirm the "soft" quality of arguments concerning direct effects.

A diminution of fears of the other turns out not to be the same as an increase in understanding. Analysis of the content of the space bridges and of audience responses makes this difference clear 
and, in fact, suggests that space bridges, at times, confirmed or augmented misunderstandings and confusions. For example, in Donahue's Citizens Summit II: Women to Women (June 1986), Soviet and American women argued with mutual distress about feminism and women's roles. It appeared to most of the American women that the women in Leningrad were unliberated and conservative about gender issues. In turn, several Soviet participants were angry at the apparent condescension of the American women. The conversation became especially tense when one Soviet woman said that she and her friends liked being "weak." This was the translator's rendition of a Russian term that is more accurately translated as "vulnerable." The Soviet woman was trying to say that she did not want to be tough (like men and some American women, it was implied); she wanted to be open and receptive. What the American women heard, however, was that Soviet women wanted to be weak and helpless, and even the most conservative of the Americans appeared puzzled by this desire.

Second, if space bridges do not always increase mutual knowledge, they have had other, unexpected effects. In the Soviet Union especially, space bridges changed the ways citizens thought about their own values and behaviors. The broadest version of this claim, now held to be common wisdom among Soviet academics and media staff, is that space bridges, the Donahue series most specifically, ushered in glasnost. According to Leonid Zolotarevsky, Gorbachev claimed that space bridges were a key to the changes that occurred in the USSR in the late-80s because they changed not only the images of Americans but self-images for the nearly 200 million people who watched them in the Soviet Union.

While the emergence of space bridges as a cultural form certainly coincided with and to some extent preceded other openings in Soviet media, there is insufficient evidence to embrace this claim as incontestable truth. There is, however, ample evidence that the broadcast of these programs in the Soviet Union was itself disconcerting to Soviet citizens. Even those directly involved in space bridge production were surprised in each instance that the programs were in fact aired. It suddenly appeared that the possibilities for alternative political activity within the Soviet Union were greater than Soviet citizens supposed.

Third, and perhaps most important, was the critical reaction of Soviet citizens as they saw themselves on television in dialogue with Americans. There is clear evidence from letters and interviews that Soviet viewers were confused, embarrassed, and distressed to witness their fellow citizens on screen lying, avoiding truths about their society, equivocating, or praising

\section{Both the Donahue and} the $A B C$ Capital to Capital space bridges dismayed many Americans because of what they saw as the arrogance and rigidity of several of the American

voices...

aspects of their society that many privately felt should be criticized. Sergei Erofeev, a Russian international television administrator and researcher, notes that silence or denial with foreigners when it comes to the difficulties of Russian/ Soviet life is a deep tradition in Russian and Soviet society. "But why should a foreigner be shown any unattractive aspects of Russia at all?" he queried recently. "This seems a natural question to many Russians to this day; they don't understand that Russia will not solve its problems so long as the question seems natural." 8

Space bridges helped to denaturalize this question for Soviet citizens. Seeing themselves in what most recognized as a "natural" form of behavior with foreigners, but in a context where most of the audience functioned much like the chorus-as-witness in a classic Greek drama, Soviet citizens appear to have experienced a unique form of self-recognition in watching space bridges: they saw themselves as evasive, intimidated, reticent, and unconfident of their own values and political practices. And they did not like what they saw.

Americans also find space bridges to be a mirror for self-reflection. Viewers of Children and Film, for example, were ashamed at the inarticulateness of American children compared to Soviet children. Both the Donahue and the ABC Capital to Capital space bridges dismayed many Americans because of what they saw as the arrogance and rigidity of several of the American voices-most notably those of the moderators and politicians-in contrast to the relatively affable and inquisitive tones of the Soviets. Behavior that seems natural or even admirable when not witnessed, or when viewed in a wholly American context, becomes the subject of criticism and reflection when viewed in an intercultural context. Soviet writer M. M. Bakhtin calls "interanimation" - the process of a culture seeing itself in the light of another. When interanimation occurs, two myths perish simultaneously: the myth of cultural uniqueness and the myth of complete cultural unity. Weakening these myths, rather than the myths of the other, seems to me the most potent effect-and possibility-of space bridges.

Finally, the more empirical aspects of my research have led me to categorize space bridges according to different types. While I initially thought these types would be best distinguished from one another in terms of television formats, economic interests, themes, and intentions, I have, instead, found it most productive to determine a set of types based on social discourse forms. Thus, I now describe space bridges in terms such as the marketplace, the Puritan town meeting, the Quaker town meeting, the classroom, the courtroom, the aca- 
demic or business conference, the festival, and oratorical contests.

Application of a set of concepts drawn from Bakhtin can lead us to a better understanding of how space bridges work. According to Bakhtin, the meaning of words or phrases is determined by the speaker and the listener. ${ }^{10}$ An utterance is always a "two-sided act" or a "bridge that depends on both sides." Space bridges as a cultural form dramatize and accentuate this fundamental quality of communication. When U.S. producers, moderators, and sponsors insist, as they have in the majority of instances, that space bridges adhere to American production values and television formats or that, more bluntly, Americans control the structure, content, and audience composition of space bridges, they are not simply being uncooperative or condescending, they are missing the point and value of the medium. Talk about production values is really talk about one set of conventions rather than another, talk that implies hegemony and resistance to difference.

Rather than encouraging and capturing the creativity inherent in dialogue (even in dialogue that appears to be didactic), producers, moderators, and video editors have tried to homogenize the event itself. Drama has been sought, first in the magic of technology and subsequently in events and contexts external to the programs themselves-human rights, journalistic practices, the potential for nuclear war-and not in the subtleties of the struggle to create new kinds of conversation. Producers and participants have attempted to reduce the kinds of speech genres apparent in space bridges to two types-conciliation and dispute-whereas the medium could be exploited to reveal the diversity and complexity of cross-cultural talk and to invent new processes of understanding. The greatest potential of space bridges is in the new forms and ideas that could come from the hybrid of joint production activity. Alone, we repeat the same forms and approaches we see on television everyday, even if the ostensible topic of the program is, say,
Russian education. Together, however, we could refract each other's conventions and a new angle of vision may appear. ${ }^{11}$

This would require different emphases and technical rules in the production of events: pre-production planning must be thoroughly collaborative; no one moderator must dominate a program; the sound of other languages must not be muted; equal visual focus must be given to those listening as to those speaking; editing must call attention to non-semantic elements of utterances such as "Well" and "Uh," laughter, applause, heads being scratched, etc. It would also require that topics and participants be chosen with an eye not toward facile agreement or opposition but toward common struggle and the pleasure and seriousness of engaging in a game that is in itself worth playing.

\section{UCSD Space Bridge Resource Center}

The UCSD Space Bridge Resource Center is an invaluable library of information concerning space bridges and an extraordinary window on the USSR toward the end of the Cold War. The Center's materials include:

- video tapes

- full-length/edited Space Bridges

- newspaper clippings

- background historical materials

- scripts

- proposals

- articles

- survey results

- student papers

- syllabi of relevant courses

The Space Bridge Resource Center is open to the public, who can copy video tapes for classroom use, research, and community showings. To acquire a complete list of video tapes, please write to Lisa Cecere, Media Assistant, Department of Communication, University of California, San Diego, La Jolla, CA, 92093. The cost of a VHS tape of a one-hour program, including mailing, is $\$ 35$ (requests for Beta and 3/4-inch formats can be accommodated; prices may vary).
Purchase orders for video tapes and printed materials should be placed with Ms. Cecere, either in writing or by phone at (619) 5346326.

\section{Notes}

1. James Hickman, a co-producer of the two earliest attempts at space bridges between music concerts in California and studios in Moscow, has shared his unpublished account of those events with me. At the time, Hickman was director of the Esalen U.S.-Soviet Exchange Program. The UCSD Resource Center holds a copy of Hickman's 90 -plus page narrative. It can be read at the archive with the author's permission. Some of the same material appears in James Hickman, 1985. Spacebridges: $A$ Handbook on Soviet American Satellite Communication [draft 2.5] Washington, D.C. Institute for Soviet-American Relations. This handbook is the precursor to the Citizen Exchange Council Handbook (1989) noted below.

2. It is worth noting that within two years, the cost of a two-hour space bridge with a one-hour edited version rose from $\$ 23,000$ to $\$ 250,000$. The 10 -fold increase reflects the assumption that many people will contribute time and equipment once but that, subsequently, everyone involved would be paid professional salaries, equipment would have to be purchased or rented and post-production editing would be included in the original budget.

3. Some idea of this production can be found in Helene Keyssar and Vladimir Pozner. 1990. Remembering War: a U.S. Soviet Dialogue. New York: Oxford University Press. Charlie Miller's contribution appears on pp. $55-60$.

4. The leading scholar on Soviet media is Ellen Mickiewicz who, from the beginning, has been supportive of the research side of this project. See Ellen Mickiewicz, Media and the Russian Public (Praeger, 1981) and Split Signals (Oxford, 1988). 5. The event never actually took place. The downing of Korean Air Lines Flight 007 occurred three days before the event. For the U.S. and the Soviet Union to jointly present a television program that ignored the disaster was inconceivable. See Helene Keyssar with Michael Cole. 1984. The Dynamics of Simulcasts. Report to the Carnegie Corporation. Available from UCSD Resource Center.

6. My main source of evidence of this is several interviews with Vladimir Pozner, including one in which he read me a number of letters from Soviets and Americans. Interviews with Soviet producers Pavel Korchagin and Sergei Skvortsov confirmed the tone and content of many Soviet responses.

7. Jennings, Peter. 1989. "Telesummitry." In Spacebridges: Television and U.S.-Soviet Dialogue, ed. Michael Brainerd. Lanham, Md:. A useful book for students and potential producers, this Citizens Exchange Council publication includes some space bridge history, a bit of context setting 
and useful "how to" hints. Jennings' comments create a provocative dialogue with his on-air performances.

8. Interview in Moscow with Sergei Erofeev (1988).

9. M.M. Bakhtin 1981. The Dialogic Imagination. Austin: University of Texas Press. p. 416-419.

10. Gary Saul Morson, ed. 1986. Bakhtin: Essays and Dialogues on his Work. Chicago: University of Chicago Press.

11. I wish to thank Charles Benton for his persistent support of my research and especially for his encouragement of the thinking I have been doing along these lines of creating new forms of television through intercultural production. I am deeply appreciative to the Benton Foundation and the MacArthur Foundation for their support of my research and production. Many thanks especially to Michael Cole without whom none of this could have possibly started or continued and to Tracy B. Strong for continuing help and support.

\begin{abstract}
About the Author
Helene Keyssar is a professor of communications at the University of California, San Diego. Her most recent book is Robert Altman's America (1992, Oxford University Press).
\end{abstract}

\title{
Oyez, Oyez, Oyez: The Trials of Teaching the Supreme Court
}

\author{
Nancy V. Baker, New Mexico State University
}

The law is more than a list of case names and facts, and courts are not neutral mechanisms dispensing "justice" like so many cans of cola. Political scientists who teach public law may feel frustrated that an anachronistic jurisprudence of impartiality continues to dominate much of the teaching about law. These faculty may find that classroom simulations, particularly mock trials, can be used to dramatize the interaction between law and politics in a way that the traditional casebook method does not. The mystique that is carefully maintained by the judiciary and many law schools can be lifted if students themselves assume the roles of particular Supreme Court justices.

One aspect of the old view of the law is the assertion that "the judge begins with some rule or principle of law as his premise, applies this premise to the facts, and thus arrives at his decision," a myth critiqued in the work of Jerome Frank in the 1930s (Frank 1963). Another aspect is the excessive but superficial deference paid to precedent, according to Karl Llewellyn (1951), since explicitly overturning prior rulings "would undermine the dogma of the infallibility of the courts" (Llewellyn 1951, 64). A third aspect is the continuing "myth of merit" outlined by David O'Brien (1990)-the notion that judicial appointments are made on the basis of merit alone.

In general, the legal system con- tinues to portray itself as above politics and personal skirmishes. Recall the judicial dismay at the 1979 publication of Woodward and Armstrong's The Brethren, and the recent release of Peter Irons's May It Please the Court, complete with tapes of oral arguments before the Supreme Court. Critical of both books, the justices have argued that secrecy is essential to maintain the prestige and credibility of the institution, e.g., the illusion that legal decisions are value neutral.

A mock trial can help to dispel these myths. Through the research stage, oral argument and conferences, student justices experience a wide range of social, personal, and political factors that contribute to the outcome of a case. A mock trial has other advantages as well: students must become personally engaged in the learning process, and active learning helps students comprehend and remember substantive material. In addition, students become acquainted during the exercise, leading to increased student participation through the rest of the semester. The format of a mock trial also provides an arena where particular legal issues may be debated, court processes dramatized, and oral skills honed. Finally, a simulation like this breaks the monotony of lecturing for both instructor and class toward the end of the term, when an infusion of enthusiasm and energy is welcome.

Simulations have been variously defined as "operating models of physical or social situations" (Nesbitt 1971,4$)$ and "simplified reality"' (Twelker and Layden 1973, 445). In a sense, they are case studies, "with the participants on the inside, not on the outside" (Jones 1980, 10-11). Classroom simulations in political science are not new, but a review of the literature suggests that they are used more extensively in the areas of public policy and international relations than in public law and the courts. ${ }^{1}$ Faculty who teach undergraduate law courses may be missing a valuable adjunct to the lecture format.

Mock trials combine two types of simulations: interpersonal and large system. An interpersonal simulation creates a scenario in which students act and react as if they were genuine players in the system. The Supreme Court simulation requires this type of role playing among participants who must assume specific personas in the decision-making process. In contrast, a large system simulation creates a more complex context in which students analyze information, make decisions, and evaluate outcomes. The emphasis, instead of being on individual behavior, is on the aggregate (Twelker and Layden 1973, 446-447). Here again the Supreme Court simulation provides opportunities, since the simulation is not truly open ended. The actors operate in a particular institutional setting, constrained by convention, case law, the Constitution, public 